\title{
Chemical compounds and antimicrobial activity of petitgrain (Citrus aurantium L. var. amara) essential oil
}

\author{
MAŁGORZATA GNIEWOSZ ${ }^{* 1}$, KAROLINA KRAŚNIEWSKA ${ }^{1}$, \\ OLGA KOSAKOWSKA ${ }^{2}$, KATARZYNA POBIEGA ${ }^{1}$, IWONA WOLSKA ${ }^{1}$
}

${ }^{1}$ Department of Biotechnology, Microbiology and Food Evaluation

Warsaw University of Life Sciences - SGGW

Nowoursynowska 159c

02-776 Warsaw, Poland

${ }^{2}$ Department of Vegetable and Medicinal Plants

Warsaw University of Life Sciences - SGGW

Nowoursynowska 159c

02-776 Warsaw, Poland

* corresponding author: e-mail: malgorzata_gniewosz@sggw.pl

\section{Summary}

Introduction: Due to its low cost and easy availability on the market, the petitgrain oil is commonly used in food, cosmetics, and aromatherapy.

Objective: The examination of chemical composition and antibacterial activity of commercial petitgrain oil.

Methods: Identification of chemical components of the petitgrain oil was performed by gas chromatography (GC). The minimum inhibitory concentrations (MIC) and minimum bactericidal/fungicidal concentrations (MBC/MFC) were determined using macrodilution method for the reference strains of bacteria and fungi.

Results: Twenty components were identified. The petitgrain oil contained mostly oxygenated monoterpene hydrocarbons (98.01\%), and the main components included linalyl acetate (48.06\%) and linalool (26.88\%). The MIC/MBC of the petitgrain oil for bacteria was in the range of $0.63-5.0 / 1.25-5.0 \mathrm{mg} / \mathrm{ml}$ and for fungi in the range of $1.25-40 / 5.0-80 \mathrm{mg} / \mathrm{ml}$.

Conclusion: The petitgrain oil had higher antibacterial activity than antifungal activity. Bacillus subtilis among the tested bacteria and Aspergillus niger and Penicillium expansum among the fungi were found to be highly inhibited by the petitgrain oil.

Key words: petitgrain, essential oil, chemical composition, antimicrobial activity 


\section{INTRODUCTION}

Citrus aurantium L. var. amara of the Rutaceae family, commonly known as bitter ("sour") orange, is regularly cultivated in the Mediterranean area and in Central and South America [1]. Composition of essential oils from bitter orange is not the same and it depends, to a large extent, on the geographic origin and parts of the plant (zest, fruit, and flowers) [2]. Essential oil from fruit zest is obtained through the cold-pressed extraction method and it is referred to as "cold-pressed essential oil". The most expensive in production is "Neroli oil", which is obtained from petals using steam distillation or hydrodistillation method [1]. Petitgrain bigarade oil is obtained by steam distillation [3] or hydrodistillation of the leaves and twigs from pruning of the trees at different times in the year [4]. Among essential oils obtained from bitter orange, petitgrain is the lowest-priced oil [5]. The largest producer of the petitgrain oil is Paraguay, followed by Egypt, Spain, France, and Italy [6]. The total production of this essential oil is estimated at 260 tons per annum [7]. Petitgrain oil is also recommended for aromatherapy, particularly for the antidepressant treatment, since it relieves anxiety, agitation, stress, and challenging behaviors [8]. Due to its low cost, and easy availability in the market, this essential oil is commonly used in the production of marmalades and in flavoring of some types of beers [9].

The study was aimed at the examination of the chemical composition and antimicrobial activity of commercial petitgrain oil against four bacterial strains, including the pathogens transferred via food and four fungi strains found in food.

\section{MATERIAL AND METHODS}

\section{Essential oil}

In this research, petitgrain essential oil (from Citrus aurantium L. var. amara) was used. The oil was purchased from the Pollena Aroma Company, Poland (commercial producer of plant essential oils and aromatic substances), from three different batches. Quality of the essential oil was ascertained to be higher than $98 \%$ pure. The oils were stored in tightly closed dark vials at $4^{\circ} \mathrm{C}$ until further tests and analysis.

\section{Identification of chemical components}

Gas chromatography analysis was performed using a Hewlett Packard 6890 gas chromatograph equipped with a flame ionization detector (FID) and capillary, polar column HP 20M $(25 \mathrm{~m} \times 032 \mathrm{~mm}$, $0.3 \mu \mathrm{m}$ film thickness). The analysis was performed following the temperature program: oven temperature isotherm at $60^{\circ} \mathrm{C}$ for $2 \mathrm{~min}$, then from $60^{\circ} \mathrm{C}$ to $220^{\circ} \mathrm{C}$ at a rate of $4^{\circ} \mathrm{C} / \mathrm{min}$ and held at $220^{\circ} \mathrm{C}$ for $5 \mathrm{~min}$. Injector and detector temperatures were set at $220^{\circ} \mathrm{C}$ and $260^{\circ} \mathrm{C}$, respectively. The carrier gas (He) flow was $1.1 \mathrm{ml} / \mathrm{min}$. The split ratio was 1:70. A total of $0.1 \mu$ of pure essential oil was manually injected. Component identification was performed by comparison of their retention times with those of pure authentic samples and by their linear retention indices (RI) relative to the series of $n$-hydrocarbons $\left(\mathrm{C}_{7}-\mathrm{C}_{30}\right)$, under the same conditions. Retention indices of compounds were also compared with those reported in the literature. The percentage composition of the oils was computed by the normalization method from the GC peak areas, without the use of correction factors. All the analyzes were performed in triplicate.

\section{Microorganisms and inoculum preparation}

The reference strains Bacillus subtilis ATCC 6633, Staphylococcus aureus ATCC 25923, Escherichia coli ATCC 25922, Salmonella ser. Enteritidis ATCC 13076, Saccharomyces cerevisiae ATCC 9763, Candida krusei ATCC 14243, Aspergillus niger ATCC 9142, and Penicillium expansum ATCC 7861 were obtained from the culture collection (Division of Food Biotechnology and Microbiology, Warsaw University of Life Sciences, Warsaw, Poland). The strains were stored in $20 \%$ glycerol at $-80^{\circ} \mathrm{C}$ in a freezer.

The frozen subcultures of bacteria were transferred to tubes containing $5 \mathrm{ml}$ of sterile nutrient broth (BTL). After incubation the test cultures of the bacteria strains were separately inoculated on slants of nutrient agar (BTL) and incubated at $37^{\circ} \mathrm{C}$ for 24 hours. Bacterial inocula were prepared in a sterile saline $(0.85 \% \mathrm{NaCl})(w / v)$ solution with the quantity corresponding to $0.5 \mathrm{McFarland}\left(\sim 1 \times 10^{8} \mathrm{cfu} / \mathrm{ml}\right)$ and diluted to $\sim 1 \times 10^{7} \mathrm{cfu} / \mathrm{ml}$.

The yeasts were separately inoculated on Sabouraud Agar slopes (SA, Merck) and were incubated at $28^{\circ} \mathrm{C}$ for 48 hours. Yeast inocula were prepared in a sterile saline solution. The density of the yeast suspension were measured with a hemocytometer and diluted as necessary with sterile saline to obtain the inoculum density of $\sim 1 \times 10^{6} \mathrm{cfu} / \mathrm{ml}$. The molds were separately inoculated on Potato Dextrose Agar 
slopes (PDA, BTL) and incubated at $28^{\circ} \mathrm{C}$ for 7 days. Slopes were flooded with $1 \mathrm{ml}$ of phosphate-buffered saline (PBS) containing $0.05 \%$ Tween 80 and gently probed to dislodge the conidia [10]. After the settling of larger particles, suspensions were adjusted by nephelometry and diluted as necessary to obtain the inoculum density of $\sim 1 \times 10^{6} \mathrm{cfu} / \mathrm{ml}$.

\section{Determination of MIC and MBC/MFC}

The antimicrobial activity of the petitgrain oil was assayed with dilution broth method according to the EUCAST guidelines [11]. Double series of petitgrain oil dilutions ranging from 0.078 to $80 \mathrm{mg} / \mathrm{ml}$ $(v / v)$ were prepared for the respective bacteria in Mueller-Hinton Broth (MHB, Merck) and for fungi in Sabouraud Broth (SB, Merck) [12] supplemented with $0.002 \%(v / v)$ of Tween 80 (Sigma-Aldrich). A negative control (medium and inoculum) was additionally prepared for each experimental series. Finally, each test tube contained $2 \mathrm{ml}$ of medium with the appropriate concentration of petitgrain oil and $0.1 \mathrm{ml}$ of inoculum.

The $100 \mu \mathrm{l}$ of inoculum containing approximately $1 \times 10^{7} \mathrm{cfu} / \mathrm{ml}$ of bacteria were transferred in $\mathrm{MBH}$ so that the final concentration in each tube was $\sim 5.0 \times 10^{5} \mathrm{cfu} / \mathrm{ml}$ and $100 \mu \mathrm{l}$ of the inoculum containing approximately $1 \times 10^{6} \mathrm{cfu} / \mathrm{ml}$ of fungi were added in $\mathrm{SB}$, so that the final inoculum concentrations were in the range of $0.4 \times 10^{4}-$ $5.0 \times 10^{4} \mathrm{cfu} / \mathrm{ml}$ [10]. A positive control (containing inoculum without petitgrain oil) was included in each series. After incubation at appropriate temperature and time (bacteria at $37^{\circ} \mathrm{C}$ for $24 \mathrm{~h}$, yeast at $28^{\circ} \mathrm{C}$ for 48 hours, and molds at $28^{\circ} \mathrm{C}$ for 72 hours), the MIC was checked. The MIC is the lowest concentration of petitgrain oil at which the bacteria and fungi failed to grow, no visible changes were detected in the broth medium.

In order to evaluate the minimum bactericidal/fungicidal concentration (MBC/MFC) of petitgrain oil, $100 \mu \mathrm{l}$ of each culture from tubes in which microbial growth was not observed was spread on Mueller-Hinton Agar (MHA, Merck) for bacteria and on Sabouraud Agar (SA, Merck) plates for fungi. Plates were incubated at appropriate temperature and time (bacteria at $37^{\circ} \mathrm{C}$ for $24 \mathrm{~h}$, yeast at $28^{\circ} \mathrm{C}$ for 48 hours, and molds at $28^{\circ} \mathrm{C}$ for 72 hours).The complete absence of growth of bacterial or fungal colonies on the agar surface at the lowest concentration of petitgrain oil was defined as the minimum bactericidal concentration (MBC) or minimum fungicidal concentration (MFC). The evaluation of MIC and MBC/MFC was carried out in triplicate.

Ethical approval: The conducted research is not related to either human or animal use.

\section{RESULTS AND DISCUSSION}

\section{Characterization of essential oil}

The chemical composition of petitgrain oil analyzed using the GC/FID is presented in table 1. Twenty chemical compounds were determined in the analyzed essential oil. The percentage content of its components was $98.90 \%$. The highest percentage of content characterized was of monoterpenoid compounds and oxygenated monoterpene hydrocarbons, which formed $98.01 \%$ of the oil. The majority of the identified compounds belong to the oxygenated monoterpene hydrocarbons: linalyl acetate (48.06\%), linalool (26.88\%), $\alpha$-terpineol (5.74\%), geranyl acetate (3.92\%), geraniol (3.05\%), and geranial $(2.44 \%)$.

Based on chemical analysis of petitgrain oil presented in this study and several other previous examinations, it can be concluded that oxygenated monoterpenes are present at higher concentrations than monoterpene hydrocarbons in the oil. Their content constitutes over $90 \%$ of total composition of petitgrain oil. The major components of petitgrain oil are linalyl acetate, linalool, $\alpha$-terpineol, and geranyl acetate $[7,13]$. Petitgrain oils originating from various areas of the world differ in the content of main components which may be due to different plant genotype, climate, and soil conditions [13, 14]. Linalool was the predominant among the main components of the Tunisian oil (62.57-22.35\%), with lower content of linalyl acetate (25.38-5.64\%) and $\alpha$-terpineol (3.0-15.69\%) [15]. The petitgrain oil originating from Greece contained $88.09 \%$ oxygenated monoterpenes, mostly linalool (58.21\%). Apart from these, the Greek petitgrain oil contained neryl acetate and trans- $\beta$ ocimene, which were not determined in the composition of commercial petitgrain oil. On the other hand, Sicilian petitgrain oil was characterized with higher values of linalyl acetate $(0.3-73.1 \%)$ and lower linalool content (8.7-16.7\%) [16]. Petitgrain oil from Turkey has a high content of oxygenated compounds $(89.6 \%)$ with linalyl acetate $(50.1 \%)$ and linalool (24.8\%) being the main components [3]. The chemical composition of petitgrain oil is further influenced 
Table 1.

Gas chromatographic composition (\% peak area) of petitgrain (Citrus aurantium L. var. amara) essential oil

\begin{tabular}{|c|c|c|c|c|}
\hline Compound & $\mathrm{RI}^{\mathrm{a}}$ & $\mathrm{RI}^{\mathrm{b}}$ & $\mathrm{RI}^{\mathrm{b}}$ range & Mean $\pm \mathrm{SD}^{\mathrm{c}}$ \\
\hline$\alpha$-Pinene & 1028 & 1025 & $1008-1039$ & $0.16 \pm 0.02$ \\
\hline$\beta$-Pinene & 1113 & 1110 & $1085-1130$ & $1.14 \pm 0.12$ \\
\hline Sabinene & 1124 & 1120 & $1098-1140$ & $0.27 \pm 0.37$ \\
\hline$\beta$-Myrcene & 1166 & 1161 & $1140-1175$ & $1.62 \pm 0.15$ \\
\hline Limonene & 1203 & 1198 & $1178-1219$ & $1.40 \pm 0.12$ \\
\hline 1,8 Cineole & 1209 & 1211 & $1186-1231$ & $0.04 \pm 0.03$ \\
\hline$y$-Terpinene & 1248 & 1245 & $1222-1266$ & $1.29 \pm 0.10$ \\
\hline p-Cymene & 1273 & 1270 & $1246-1291$ & $0.06 \pm 0.01$ \\
\hline$\alpha$-Terpinolene & 1278 & 1282 & $1261-1300$ & $0.23 \pm 0.02$ \\
\hline Linalool & 1540 & 1543 & $1507-1564$ & $26.88 \pm 0.88$ \\
\hline Linalyl acetate & 1557 & 1554 & $1532-1570$ & $48.06 \pm 1.05$ \\
\hline$\beta$-Caryophyllene & 1593 & 1588 & $1570-1685$ & $0.96 \pm 0.04$ \\
\hline Isoborneol & 1657 & 1659 & $1635-1675$ & $0.09 \pm 0.01$ \\
\hline$\alpha$-Terpineol & 1681 & 1694 & $1659-1724$ & $5.74 \pm 0.11$ \\
\hline Borneol & 1687 & 1699 & $1653-1728$ & $0.35 \pm 0.01$ \\
\hline Geranial & 1722 & 1725 & $1680-1750$ & $2.44 \pm 0.12$ \\
\hline Geranyl acetate & 1731 & 1751 & $1728-1772$ & $3.92 \pm 0.23$ \\
\hline Nerol & 1795 & 1794 & $1752-1832$ & $1.36 \pm 0.31$ \\
\hline Geraniol & 1826 & 1839 & $1795-1865$ & $3.05 \pm 0.04$ \\
\hline Caryophyllene oxide & 1955 & 1986 & $1936-2023$ & $0.08 \pm 0.02$ \\
\hline Identified components [\%] & & & & 99.14 \\
\hline \multicolumn{5}{|l|}{ Grouped components } \\
\hline Monoterpene hydrocarbons & & & & 6.17 \\
\hline $\begin{array}{l}\text { Oxygenated monoterpene } \\
\text { hydrocarbons }\end{array}$ & & & & 91.93 \\
\hline Sesquiterpene hydrocarbons & & & & 0.96 \\
\hline $\begin{array}{l}\text { Oxygenated sesquiterpene } \\
\text { hydrocarbons }\end{array}$ & & & & 0.08 \\
\hline
\end{tabular}

Notes: $\mathrm{RI}^{\mathrm{a}}$ - etention index relative on HP-20M capillary column; RI - average retention indices on polar column reported by Babushok et al. [13], $\mathrm{RI}^{\mathrm{b}}$ range - range of retention indices on polar column reported by Babushok et al. [13]; $\mathrm{SD}^{\mathrm{c}}$ - standard deviation, $n=3$

by the procedure and the time of extraction from the plant raw material [15]. Ellouze and Abderrabba [15] determined that during hydrodistillation of essential oil from C. aurantium leaves for $180 \mathrm{~min}$, a decline in monoterpene content was observed (89.93-47.32\% in $15 \mathrm{~min}$ and $165 \mathrm{~min}$, respectively), while the sesquiterpene content increased. Ellouze et al. [4] have found the effect of seasonal variations of leaves collection on chemical composition of essential oils. The essential oils obtained from the fresh leaves of C. autrantium L. ssp. aurantium, which were gathered during January noted 14 components only, while the July one presented 35 among the 46 identified components.

\section{Antimicrobial activity of petitgrain oil}

The evaluation of antimicrobial activity of petitgrain oil was conducted in compliance with the standardized techniques, determining the minimum inhibitory concentrations (MIC) that inhibits the growth of microbes and minimum bactericidal and fungicidal concentrations (MBC/MFC). The assessment of the efficiency of petitgrain oil was conducted for the reference test strains of bacteria and fungi.

The MIC and MBC/MFC of petitgrain oil are presented in table 2 . The highest inhibitory activity of petitgrain oil was determined for bacteria, including Gram-positive bacteria. The MIC values 
Table 2.

The antimicrobial activity of petitgrain essential oil

\begin{tabular}{llll}
\hline & & MIC & MBC \\
\cline { 3 - 4 } & B. subtilis ATCC 6633 & & $\mathrm{mg} / \mathrm{ml}$ \\
\hline S. aureus ATCC25923 & 0.63 & 1.25 \\
\hline Bacteria & E. coli ATCC 25922 & 1.25 & 5 \\
\hline & S. ser. Enteritidis ATCC 13076 & 2.5 & 5 \\
\hline S. cerevisiae ATCC 9763 & 5 & 5 \\
\hline A. niger ATCC 9142 & 2.5 & 5 \\
\hline
\end{tabular}

of petitgrain oil for B. subtilis and S. aureus bacteria remained in the range of $0.63-1.25 \mathrm{mg} / \mathrm{ml}$, while the MBC values were $1.25-5.0 \mathrm{mg} / \mathrm{ml}$. The Gramnegative bacteria strains of $E$. coli and $S$. ser. Enteritidis were less susceptible to the effect of petitgrain oil. The MIC and MBC values remained in the range between 2.5 and $5.0 \mathrm{mg} / \mathrm{ml}$.

The weakest antimicrobial activity of petitgrain oil was observed against fungi. The MIC of petitgrain oil for the inhibition of P. expansum and $A$. niger mold was $1.25 \mathrm{mg} / \mathrm{ml}$. In the case of $S$. cerevisiae yeast, the MIC and MFC values were $2.5 \mathrm{mg} / \mathrm{ml}$ and $5.0 \mathrm{mg} / \mathrm{ml}$, respectively. The weakest fungicidal effect of petitgrain oil was observed for C. krusei.

The antimicrobial activity of essential oils is typically linked to their main components [17]. Petitgrain oil is characterized with high content of oxygenated monoterpenes, mostly linalyl acetate $(48.06 \%)$ and linalool (26.88\%) (tab. 1). The mechanism of antimicrobial activity of these compounds stems from their lipophilic character, creating strong affinity to plasma membranes of microorganisms and strong toxicity [18]. Linalyl acetate and limonene preferentially divide from an aqueous phase and enter into the plasma membrane structures. Accumulation of linalyl acetate and limonene in the membrane damages the composition and structure of plasma membrane, causing the increase of plasma membrane fluidity and leakage of intracellular molecules from the cell. Blaskó et al. [18] confirmed that these disturbances in plasma membrane determine the cell death of Candida albicans. Similar effect is attributed to 1,8-cyneol, which modifies the characters of cellular membranes by rupturing the hydrogen bonded network at the membrane-water interface. Monoterpene alcohols ( $\alpha$-terpineol and 1,8-cineole) have a similar effect on microbial cells, i.e., they interact with plasma membranes [12]. At relatively low concentrations, such interactions may lead to changes like respiratory inhibition and altered permeability [19], and at higher concentrations they may lead to a complete loss of homeostasis, plasma membrane damage, and death. Monoterpene alcohols are considered to be efficient against microbes due to their relatively high water solubility and the presence of the alcohol moiety [19].

There are published data from previous studies regarding the antimicrobial activity of essential oils produced from flowers and fruits of Citrus aurantium L. var. amara, but no data is available on the antimicrobial activity of petitgrain oil. Ellouze et al. [4] registered that petitgrain oils were most effective against Gram-positive bacteria (S. aureus and $L$. monocytogenes were more sensitive to the essential oils), and weak against Gram-negative strains. Essential oil from bitter orange flowers examined by Hsouna et al. [17] inhibited the growth of both Gram-positive and Gram-negative bacteria in the concentration range from $0.312-2.5 \mathrm{mg} / \mathrm{ml}$ and $0.625-2.5 \mathrm{mg} / \mathrm{ml}$, respectively. The fungistatic activity of this essential oil was even stronger. The MIC for molds of the genus Aspergillus was in the range of $0.078-1.25 \mathrm{mg} / \mathrm{ml}$ and for Fusarium, it was $0.156-1.25 \mathrm{mg} / \mathrm{ml}$. A comparison of MIC values of both the essential oils from Citrus aurantium L. var. amara demonstrated that antimicrobial activity of the oil from flowers was stronger than the oil from leaves and twigs (petitgrain) of the plant. The flower oil contained considerably higher amounts of monoterpene hydrocarbons (36.2\%), sesquiterpene hydrocarbons (4.1\%), and oxygenated sesquiterpene hydrocarbons $(26.2 \%)$, which were present in the examined petitgrain oil at $6.17,0.96$, and $0.08 \%$, respectively. Strong fungicidal activity is also exhibited 
by limonene and (E)-nerolidol, which were present in the flower essential oil at concentrations 27 and $17.5 \%$, respectively. In the petitgrain oil, limonene was present only at a concentration of $1.4 \%$.

The unequal effect of the oil is linked to the difference in its composition of active compounds. Monoterpenes might be responsible for the antifungal effect of the petitgrain oil. Hammer et al. [19] demonstrated monoterpene activity toward yeasts and filamentous fungi. In the study, it was determined that Candida albicans and C. tropicalis are characterized by high susceptibility to monoterpene mixtures. High antifungal activity is also exhibited by terpinen- 4 -ol, $\alpha$-pinen, $\beta$-pinen, 1,8-cyneol, linalool, and 4-terpineol. This mixture of terpenoid metabolites inhibits the growth of dermatophytes, such as Trichophyton mentagrophytes, T. rubrum, and Microsporum gypseum, and also the filamentous fungi Aspergillus niger and A. flavus [20].

\section{CONCLUSION}

Essential oils are natural plant products containing mixture of components and thus having multiple antimicrobial properties. In the petitgrain essential oil, the GC/FID analysis allowed to identified 20 compounds. The major components of essential oil was linalyl acetate (48.06\%) and linalool (26.88\%).

The results of the study may suggest effective antimicrobial activity of petitgrain essential oil. It was found that tested oil effectively inhibits the growth of Gram-positive bacteria. Less sensitive to the inhibitory activity were Gram-negative bacteria and fungi. This finding also highlights the potential use of the petitgrain essential oil as inhibitors of food spoilage and pathogenic microorganisms.

\section{ACKNOWLEDGEMENTS}

The work was funded as statutory research by the Department of Biotechnology, Microbiology and Food Evaluation, Faculty of Food Science, Warsaw University of Life Sciences-SGGW.

Conflict of interest: Authors declare no conflict of interest.

\section{REFERENCES}

1. Bourgou S, Rahali FZ, Ourghemmi I, Saïdani Tounsi M. Changes of peel essential oil composi- tion of four Tunisian citrus during fruit maturation. Sci World J 2012; 528593. doi: http://dx.doi. org/10.1100/2012/528593

2. Zhao HY, Yang L, Wei J, Huang M, Jiang JG. Bioactivity evaluations of ingredients extracted from the flowers of Citrus aurantium L. var. amara Engl Food Chem 2012; 135:1275-1281.

3. Kirbaslar G, Kirbaslar SI. Composition of Turkish bitter orange and lemon leaf oils. J Essent Oil Res 2004; 16:105-108.

4. Ellouze I, Abderrabba M, Sabaou N, Mathieu F, Lebrihi A, Bauajila J. Season's variation impact on Citrus aurantium leaves essential oil: chemical composition and biological activities. J Food Sci 2012; 77(9):T173-80.

5. Do TKT, Hadji-Minaglou F, Antoniotti S, Fernandez X. Authenticity of essential oils. TrACTrend Anal Chem 2015; 66:146-157.

6. Caiger S. Essential oils and oleoresins market insider. http://www.intracen.org/itc/market-insider.

7. Lota ML, de Rocca Serra D, Jacquemond C, Tomi F, Casanova J. Chemical variability of peel and leaf essential oils of sour orange. Flavour Frag J 2001; 16:89-96.

8. Ali B, Al-Wabel NA, Shams S, Ahamad A, Khan SA, Anwar F. Essnetial oils used in aromatherapy: A systemic review. Asian Pac J Trop Biomed 2015; 5:601-611.

9. Kiple KF, Ornelas KC. The Cambridge World History of Food. Cambridge 2000:1822-1826.

10. Hammer KA, Carson CF, Riley TV. In vitro activity of Melaleuca alternifolia (tea tree) oil against dermatophytes and other filamentous fungi. J Antimicrob Chemother 2002; 50:195-199.

11. International Organization for Standards. ISO 20776-1. Clinical laboratory testing and in vitro diagnostic test systems - Susceptibility testing of infectious agents and evaluation of performance of antimicrobial susceptibility test devices - Part 1: Reference method for testing the in vitro activity of antimicrobial agents against rapidly growing aerobic bacteria involved in infectious diseases. International Organization for Standards, Geneva, Switzerland. 15 Nov 2006. 
12. Nascente PS, Meinerz ARM, Faria RO, Schuch LPD, Meireles MCA, Mell JRB. CLSI broth microdilution method for testing susceptibility of Malassezia pachydermatis to thiabendazole. Braz J Microbiol 2009; 40:222-226.

13. Babushok VI, Linstrom PJ, Zenkevich IG. Retention indices for frequently reported compounds of plant essential oils. J Phys Chem Ref Data 2011; 40(4). doi: http://dx.doi.org/10.1063/1.3653552.

14. Azadi B, Nickavar B, Amin G. Volatile constituents of the peel and leaf of Citrus aurantium L. cultivated in the north of Iran. J Pharm Health Sci 2012; 1:37-41.

15. Ellouze I, Abderrabba M. Kinetics of extraction of Citrus aurantium essential oil by hydrodistillation: influence on the yield and the chemical composition. J Mater Environ Sci 2014; 5:841848.

16. De Pasquale F, Siragusa M, Abbate L, Tusa N, De Pasquale C, Alonzo G. Characterization of five sour orange clones through molecular markers and leaf essential oils analysis. Sci Hort 2006; 109:54-59.

17. Hsouna AB, Hamdi N, Halima NB, Abdelkafi S. Characterization of essential oil from Citrus aurantium L. flowers: antimicrobial and antioxidant activities. J Oleo Sci 2013; 62:763-772.

18. Blaskó A, Gazdag Z, Gróf P, Máté G, Sárosi S, Krisch $J$ et al. Effects of clary sage oil and its main components, linalool and linalyl acetate, on the plasma membrane of Candida albicans: an in vivo EPR study. Apoptosis 2016; 22(2):175-187.

19. Hammer KA, Carson CF, Riley TV. Antifungal activity of the components of Melaleuca alternifolia (tea tree) oil. J Appl Microbiol 2003; 95:853860.

20. Griffin SG, Wyllie SG, Markham JL, Leach DN. The role of structure and molecular properties of terpenoids in determining their antimicrobial activity. Flavour Frag J 1999; 14: 322-332.

\title{
Skład chemiczny i aktywność przeciwdrobnoustrojowa olejku eterycznego petitgrain (Citrus aurantium L. var. amara)
}

\author{
MAŁGORZATA GNIEWOSZ ${ }^{1 \star}$, KAROLINA KRAŚNIEWSKA ${ }^{1}$, \\ OLGA KOSAKOWSKA ${ }^{2}$, KATARZYNA POBIEGA ${ }^{1}$, IWONA WOLSKA ${ }^{1}$
}

\author{
${ }^{1}$ Katedra Biotechnologii, Mikrobiologii i Oceny Żywności \\ Szkoła Główna Gospodarstwa Wiejskiego w Warszawie \\ ul. Nowoursynowska 159C \\ 02-776 Warszawa \\ ${ }^{2}$ Katedra Roślin Warzywnych i Leczniczych \\ Szkoła Główna Gospodarstwa Wiejskiego w Warszawie \\ ul. Nowoursynowska 159C \\ 02-776 Warszawa \\ *autor, do którego należy kierować korespondencję: malgorzata_gniewosz@sggw.pl
}

\section{Streszczenie}

Wstęp: Olejek eteryczny petitgrain ze względu na niewielki koszt i dostępność na rynku jest często stosowany w produkcji żywności, kosmetyków i aromaterapii. 
Cel: Zbadano skład chemiczny i aktywność przeciwdrobnoustrojową handlowego olejku petitgrain.

Metodyka: Identyfikację chemicznych składników olejku petitgrain wykonano przy użyciu chromatografii gazowej (GC). Minimalne stężenia hamujące (mic) oraz minimalne stężenia bakteriobójcze/grzybobójcze (MBC/MFC) zostały oznaczone metodą makrorozcieńczeń wobec referencyjnych szczepów bakterii i grzybów.

Wyniki: Zidentyfikowano dwadzieścia kompotentów. Olejek petitgrain zawierał najwięcej utlenionych węglowodorów monoterpenowych (98.01\%), a głównymi składnikami były: octan linalilu (48,06\%) i linalool (26,88\%). MIC/MBC olejku petitgrain wobec bakterii były w granicach $0,63-5,0 / 1,25-5,0 \mathrm{mg} / \mathrm{ml}$, a wobec grzybów były w zakresie 1,25-40/5,0-80 mg/ml.

Wnioski: Olejek petitgrain miał większą aktywność przeciwbakteryjną niż przeciwgrzybiczną. Spośród badanych bakterii Bacillus subtilis, a spośród grzybów Aspergillus niger i Penicillium expansum były najsilniej hamowane przez olejek petitgrain.

Słowa kluczowe: petitgrain, olejek eteryczny, skład olejku eterycznego, aktywność przeciwdrobnoustrojowa 